\title{
Gene Flow in Volant Vertebrates: Species Biology, Ecology and Climate Change
}

\author{
Kritika M. Garg ${ }^{1,2}$ (D) and Balaji Chattopadhyay ${ }^{3^{*}}$ (])
}

\begin{abstract}
Gene flow, the exchange of genetic material between populations is an important biological process, which shapes and maintains biodiversity. The successful movement of individuals between populations depends on multiple factors determined by species biology and the environment. One of the most important factors regulating gene flow is the ability to move, and flight allows individuals to easily move across geographical barriers. Volant vertebrates are found on some of the remotest islands and contribute significantly to the biodiversity and ecosystem. The availability of next-generation sequencing data for non-model animals has substantially improved our understanding of gene flow and its consequences, allowing us to look at fine-scale patterns. However, most of our understanding regarding gene flow comes from the temperate regions and the Neotropics. The lack of studies from species-rich Asia is striking. In this review, we outline the importance of gene flow and the factors affecting gene flow, especially for volant vertebrates. We especially discuss research studies from tropical biomes of South and Southeast Asia, highlight the lacuna in literature and provide an outline for future studies in this species-rich region.
\end{abstract}

Keywords: Bats, Birds, Gene flow, South Asia, Southeast Asia; Volant vertebrates

\section{Introduction}

Gene flow is the movement of individuals/genes between populations ${ }^{74,75}$. It allows for genetic exchange and connectedness between populations thereby countering the diversifying effects of genetic drift, mutation and selection ${ }^{22,74,75}$. Gene flow is, therefore, necessary to maintain the potential for the evolution of a species by regulating its genetic diversity ${ }^{21}$. Often considered as a restraining force, gene flow can on one hand nullify population differentiation or local adaption patterns, and on the other hand acts as an active evolutionary force leading to the spread of adaptive/novel genes between populations 22, 75 . Genetic exchange is particularly critical for the survival of insular and endangered populations/ species thereby making it one of the most important component for conservation programs ${ }^{21}$. However, the lack of gene flow not only endangers survival but can also act as an active agent for speciation, both across an evolutionary time scale wherein a gradual decrease of genetic connectivity slowly segregates isolated populations which eventually forms new species, and also across ecological timescale wherein ecological adaptation can swiftly act upon isolated populations segregating them into distinct species ${ }^{59,75}$, for exceptions see 37,38

While allowing for the exchange of alleles, gene flow in natural populations increase genetic variability and connects not only geographically isolated populations but also evolutionary divergent species-level lineages ${ }^{28,44,83}$. The process of successful reproduction between two species is known as hybridization and the process of introduction of novel genetic material from one species to another when fertile hybrids successfully mate with either one or both of the parent species is known as introgression ${ }^{44,69}$. Contingent upon species history and environment, divergent
Gene flow: exchange of genetic material between populations/species.

Genetic drift: change in allele frequency of a population over generations due to chance.

Mutation: a change in DNA sequence due to mistakes during replication or exposure to mutagenic agents.

Selection: increased survival and reproduction in individuals with certain genotypes in comparison to others.

Hybridization: successful reproduction and exchange of genetic material between two species.

Introgression: incorporation of genetic material of one species to another through the process of hybridization and backcrossing.

${ }^{1}$ Institute of Bioinformatics and Applied Biotechnology, Bengaluru, Karnataka, India. ${ }^{2}$ Department of Biology, Ashoka University, Sonipat, Haryana, India. 3 Trivedi School of Biosciences, Ashoka University, Sonipat, Haryana, India. *balaji.chattopadhyay@ ashoka.edu.in 
Hybrid zone: area of overlap between two species where both genetically pure, hybrids and introgressed individuals can be observed. lineages can come in secondary contact thereby exchanging genetic material and forming hybrid zones. Hybrid zones play a significant role in speciation dynamics. They provide the only natural settings to test reproductive barriers between closely related sympatric lineages ${ }^{46,83}$. At times, hybrids upon the effect of natural selection can also evolve into distinct species (hybrid species) thereby enhancing biodiversity ${ }^{83}$. In general, hybridization and introgression in hybrid zones is generally a pervasive force leading to homogenization and loss of differences between species and blurring species boundaries ${ }^{83}$. However, on the other hand, introgression can be also beneficial through the introduction of novel variation in a species, like cases of adaptive introgression of red wing pattern genes from Heliconius melpomene into $H$. cydno, introgression of pesticide resistance genes from Anopheles gambiae into A. coluzzii; and introgression of rodent poison resistance from Mus spretus to Mus musculus domesticus $28,44,58,64,76,83$. In extreme circumstances, introgression from invasive species can also replace and deplete the genetic diversity of the native biota thereby endangering biodiversity. For example, in the North American hybrid zones where the closely related golden-winged and blue-winged warblers frequently mate and hybridize, the golden-winged warblers experience genomic invasion from the blue-winged warblers, concomitant range contractions, and endangerment 24, 84. Although previously considered uncommon in animals, the past two decades have seen an enormous rise in the number of publications documenting introgression in all major branches of the tree of life, especially with the application of next-generation sequencing (NGS) data ${ }^{61}$.

Most of our understanding about gene flow and its effects come from studies of natural populations from the temperate regions and the Neotropics. However, the highly heterogeneous landscape of tropical South and Southeast Asia comprising some of the most species-rich regions, multiple biodiversity hotspots, and home to major biogeographic barriers, form the perfect settings to discuss the evolutionary significance of gene flow in shaping biotic diversity ${ }^{53,81}$. Hence a comprehensive review of the current status of the gene flow research in this region is necessary. South and Southeast Asia are also home to an intricate network of island systems which are engines of biotic diversification and provide a natural laboratory to test various evolutionary theories. In the following sections we will discuss the importance of gene flow in shaping the current biodiversity, and examine various factors that affect gene flow in the wild, with a greater emphasis on studies from island systems and complex habitats. Throughout the review, we attempt to highlight examples from South and Southeast Asia. However, such case studies are scant compared to studies from the Neotropics or from the Northern hemisphere. While lack of generous funding is a major hurdle in South and Southeast Asia, difficulty in obtaining necessary permits is another major limiting factor contributing to the lack of progress in gene flow research in this region. Only a few research groups have been able to establish long-term and dedicated monitoring projects, which are necessary to address evolutionary questions. Further, many areas are not accessible due to either difficult terrain or conflict. It is necessary to establish long-term collaborative projects, build capacity by training local researchers and implement successful technology transfers to establish longterm gene-flow-based research programs in this biodiverse region. For the purposes of the current review, owing to the paucity of available literature from South and Southeast Asia, case studies from the Neotropics and temperate regions are also discussed to highlight recent advancements in our overall understanding of the causes and consequences of gene flow.

\section{Volant Vertebrates and Gene Flow}

Owing to their capability to fly, volant vertebrates can traverse great distances, colonise distant islands, cross steep environmental gradients, and thus forms an important study system to understand the evolutionary contingents of gene flow across complex landscapes ${ }^{49}$. Volant vertebrates are ubiquitous and present in virtually every habitat. They are species-rich groups with high biodiversity and are important bioindicators ${ }^{6,35}$. For example, the number of birds in a breeding area can indicate the bioproductivity and habitat quality of the region ${ }^{4}$. Similarly, insect bat diversity and abundance are directly correlated to arthropod diversity ${ }^{35}$. They are keystone species playing an important role in pollination, seed dispersal, and pest management ${ }^{1,35}$. Both birds and bats are endotherms and face similar selection pressures on their morphology and physiological traits due to their ability to fly. Miniaturization of body size, prolonged lifespan, smaller but effective digestive tract, high metabolic rate and antioxidant capacity, smaller genomes are some of the common traits observed in both birds and bats ${ }^{55}$. 
However, some differences also exist, like birds tend to live longer for their body size, even compared to bats ${ }^{5,55}$. Both birds and bats are significant carriers of viruses of zoonotic potential, however, birds tend to have lower viral loads. Birds also differ in their immune response in general compared to mammals, however, both birds and bats are generally tolerant to viruses and hence are able to co-exist with multiple potentially pathogenic viruses ${ }^{55}$ and references therein). Given the high load of viruses in both birds and bats, it is important to understand the patterns of gene flow in volant vertebrates due to their ability to move long distances and potential to spread viruses across remote landscapes ${ }^{27,39}$. Bats are one of the most important mammalian reservoirs of RNA viruses and have been implicated in multiple zoonotic outbreaks like SARS (severe acute respiratory syndrome), MERS (Middle East respiratory syndrome), Nipah and Hendra to name a few ${ }^{39}$. Similarly, birds are associated with zoonotic diseases like avian flu, psittacosis, salmonellosis among others ${ }^{27}$. They can easily transfer viruses over large distances and potentially infect healthy populations. Hence a thorough understanding of the evolutionary contingents of gene flow in these animals can also help us to understand its role in host-pathogen coevolution. We will specifically review the volant vertebrate literature, present recent advances in our understanding of patterns of gene flow with the availability of large scale genomic data from non-model organisms, highlight the bias and lacunae in the current literature and propose future directions of the study of gene flow in volant vertebrates across complex landscapes.

\section{Quantifying Gene Flow in Natural Populations}

It should be noted that gene flow and dispersal are not the same and gene flow assumes that the individual that has dispersed to a new population successfully reproduces and is able to contribute to the gene pool of the next generation ${ }^{74,89}$. Both protein and nucleic acids can be used as genetic markers to quantify gene flow. DNA based markers such as microsatellite, single nucleotide variation (SNPs), sequence data tend to work better than protein makers due to their high resolution. With the advent of NGS platform for non-model organisms, we have gained unprecedented power in quantifying gene flow levels in natural populations. Gene flow can be quantified using direct and indirect methods. Direct methods involve genotyping individuals belonging to at least two generations and performing parentage analysis to identify migrants parents. This can be supplemented with actual dispersal data obtained using behavioural studies $5,74,74,89$. However, it is very tedious to estimate gene flow directly and hence a plethora of indirect methods to quantify gene flow have been devised. Indirect methods involve quantifying population subdivision and inferring the possible rate of gene flow from the variance in allele frequencies ${ }^{74,89}$. There are many methods to quantify gene flow from simple fixation index-based measures to more complex coalescent modelling based approaches. Details of these methods have already been reviewed previously and are beyond the scope of this review (see ${ }^{45,62}$, ${ }^{74,89}$ for more details).

\section{Factors Affecting Gene Flow 4.1 Species Attributes}

Gene flow can be studied at multiple levels, between geographically proximate groups to populations across continents; between social units to closely related species; and across various evolutionary timescales, both contemporary as well as ancient. Both species biology and the environment (historic and present) interact and determine the levels of gene flow (Figs. 1 and 2). As gene flow characterizes successful movement of individuals between populations over generations, the ability of a species to move becomes an important predictor of its genetic connectivity across large distances ${ }^{49}$. Life-history attributes along with the geographical landscape determine the genetic variability and ability for genetic exchange between populations. Small and sedentary species often show greater isolation across large distances compared to large-bodied animals who can traverse greater distances and maintain genetic connectivity across large areas $49,63,82$. A comparison of population structure in 40 species of frogs from Madagascar suggested that small-sized frogs were unable to travel large distances and showed higher levels of genetic differentiation in comparison to frogs with large body size ${ }^{63}$. Similarly a study on genetic connectivity between populations of jungle cat, leopards, sloth bears, and tigers in central India, suggested that both body size and habitat feature interact to determine the level of gene flow and genetic connectivity between populations ${ }^{82}$. Body size was also an important determinant for genetic connectivity in Caribbean mastiff bats, with ocean being a barrier to gene flow in small bats but 


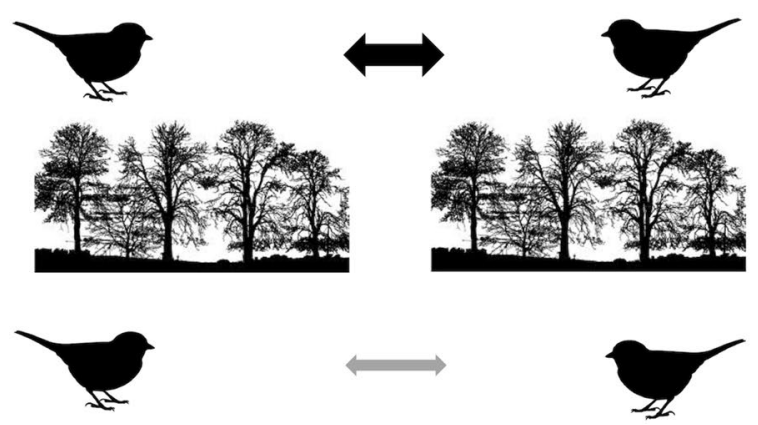

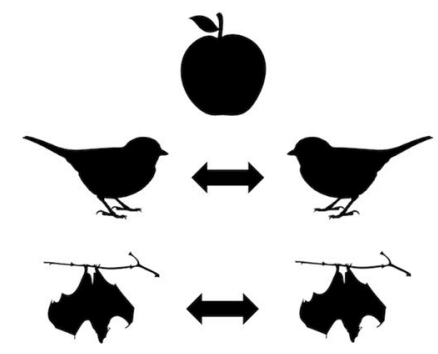

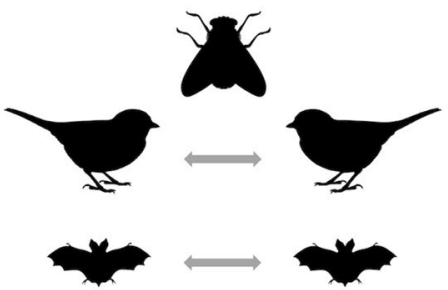

Figure 1: Differential pattern of gene flow based on life-history in many volant vertebrates. a higher levels of gene flow can be observed in canopy birds compared to understory birds, and $\mathbf{b}$ higher levels of gene flow can be observed in frugivores compared to insectivores. Black arrows depict higher levels of gene flow in comparison to grey arrows. Clipart were obtained from http://clipart-library.com

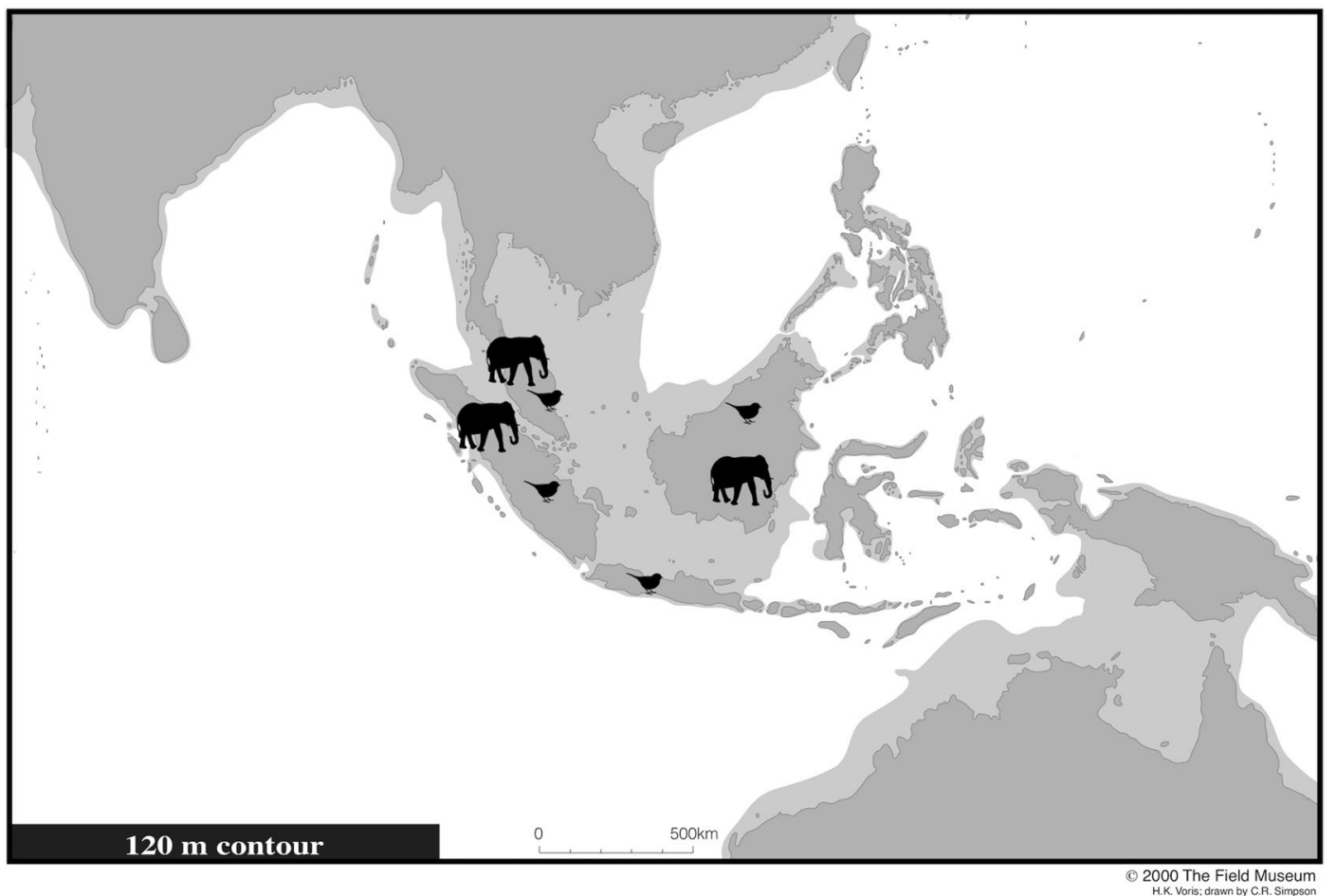

Figure 2: Map depicting the current coast line of South and Southeast Asia shown in dark grey and emergent landmass shown in light grey, when the sea level drops by $120 \mathrm{~m}$ during periods of global cooling. Formation of land bridges during the periods of glacial maxima and climate cooling facilitated movement of both terrestrial and volant vertebrates between isolated landmasses. Map was reproduced and modified with permission from Voris ${ }^{86}$ from Field Museum, Chicago, USA. Clipart were obtained from http://clipart-library.com 
inconsequential for larger bats, which were able to fly across oceanic barriers ${ }^{41}$. Interestingly, the correlation between body size and dispersal ability in birds is low ${ }^{73,79}$. Migratory behaviour in polar birds isstrongly correlated with hand-wing index (HWI), an estimate of wing-tip pointedness ${ }^{73}$. Tropical bird species tend to be sedentary in nature compared to the species in the polar regions, due to low variation in breeding territories and high resources ${ }^{73,79}$.

Mode of locomotion is also an important attribute that affects gene flow as it determines the dispersal distance, and thus the levels of genetic connectivity. For example, terrestrial species will be less mobile compared to species that can fly. Volant vertebrates may find it easier to cross certain barriers like rivers, bad habitat, roads etc. and a comparison of genetic differentiation across 400 vertebrates, confirmed this pattern that species with high vagility and mobility tend to have low levels of genetic differentiation ${ }^{49}$. Due to their flight ability, bats are the only native land mammals from islands of New Zealand, Hawaii and other Pacific islands ${ }^{20}$. However, even for volant vertebrates, species biology remains a strong determinant of the ability to move great distances and cross biogeographic barriers ${ }^{51}$. Birds and bats often reveal this effect while travelling to distant landmasses, across environmental clines or crossing biogeographic barriers. For example, in a comparative study of genetic connectivity in bats and rodents from Philippines, the rodents showed high differentiation and low genetic connectivity similar to the forest-dependent bat species (habitat specialists), whereas bats living in disturbed habitats (generalists) were easily able to cross the oceanic barriers ${ }^{29}$. Even when there are no physical barriers to gene flow, distance can become an important factor determining population subdivision and isolation. Genetic break in connectivity is observed over large distances as in the case of short-nosed fruit bat, with populations from Southern India being isolated from Eastern India ${ }^{11}$.

At the microgeographic level, social structure and mating system determines the movement between social groups and populations. Sexbiased dispersal is observed in many animals and is driven by the mating system ${ }^{25,67}$. For example, in monogamous birds, female-biased sex dispersal is observed whereas in polygynous territorial mammals (including volant mammals), generally males leave their natal sites to establish new breeding territories ${ }^{25,67}$. Although, dispersal is a costly strategy, exposing the migrants to multiple risks like predation, starvation, aggression, etc., it is a common phenomenon across the tree of life. The cost associated with dispersal is offset by multiple benefits that can be acquired by the dispersing individuals. For example, sex-biased dispersal can help in countering the ill effects of genetic drift and inbreeding and avoid competition for resources ${ }^{65,67}$. Dispersal distance in great tit was inversely related to inbreeding, with individuals dispersing short distance exhibiting higher levels of inbreeding ${ }^{80}$. In bats, male-biased dispersal reduces the ill effects of inbreeding in Bechstein's bat by allowing genetic exchange between populations. In many species of bats, females are philopatric and form large maternal colonies. Although, most females within these maternal colonies are related, overall population relatedness is close to zero, possibly due to malebiased dispersal ${ }^{36}$.

Another important factor determining genetic connectivity is species ecology and niche preference. Generalist species are able to move across poor habitat, whereas this maybe an impediment for niche specialists (Fig. 1) ${ }^{7,23}$. In spite of their ability to fly, this pattern is also observed in volant vertebrates. For example, in Amazonian birds, floodplain and forest edge species populations were homogeneous compared to upland forest species ${ }^{7}$. Low levels of gene flow and population divergence were observed in forest species. Similarly, canopy birds were easily able to cross across barriers, while forest species were restricted in their movement (Fig. 1a) ${ }^{7}$. Volant mammals too follow these general patterns of population subdivision. Low levels of population structure are expected in bats due to the ability to fly, especially in migratory species of bats low levels of population subdivision is observed in comparison to non-migratory species due to the ability to move long distances ${ }^{51}$. For example, haplotype sharing was observed over $2800 \mathrm{~km}$ in the migratory southern long-nosed bat ${ }^{91}$. Similarly, small cave roosting bats from Andaman islands exhibit population subdivision, however, the large frugivores bats were able to move across islands and display no population subdivision (Fig. 1b) ${ }^{9}$.

\subsection{Climate and Habitat Fragmentation}

At the macrogeographic level, gene flow between geographically isolated populations is determined by both habitat and earth climatic history (Fig. 2). Paleo climate has played a key role in shaping the current biotic diversity ${ }^{30,31}$. For the past 2.6 million years, earth has undergone multiple cooling and warming cycles. Known as the Quaternary, this period has led to episodic
Inbreeding: breeding of closely related individuals. 
isolation and connectivity between natural populations leading to the gradual divergence of many taxa across the globe ${ }^{30,31}$. In the temperate latitudes and high-altitude mountain ranges, glaciers and ice sheets expand during periods of climatic cooling covering continental landmasses in temperate regions with ice sheets, and leaving little pockets of suitable habitable environmental conditions for biotic survival 30,31 . Distribution ranges of many animals shrink and are largely confined into refugia in the southern latitudes, leading to isolation and speciation in many cases ${ }^{30,31}$. The number and quality of corridors largely characterizes the extent of connectivity between refugial populations contingent of species biology and ecology. For example, many species in Europe were restricted to few pockets of suitable habitat in the Iberian Peninsula, Italy, and the Balkans during the Last Glacial Period ${ }^{30}$. Only once the ice retreated, the rest of Europe was recolonized. General patterns of colonization can be drawn based on the area of glacial refugia. For example, the Balkans was an important refugia and contributed significantly to the current diversity of Eastern as well as Western Europe ${ }^{30}$. The Alps and Pyrenees mountain ranges continued to act as barriers to the movement of animals out of Italy to northern Europe even when suitable habitat became available during the warmer periods ${ }^{30,31}$. Similarly, during periods of climatic cooling, in higher altitude mountain ranges ice caps form and ice sheets extend to lower altitudes, again pushing high altitude specialists into local pockets of refugia along the ice-free valleys, and shifting biotic communities to lower altitudes, allowing for genetic exchange between otherwise isolated montane populations ${ }^{30,31}$. On one hand, such events of episodic isolation may eventually lead to speciation, on the other hand, secondary contacts of closely related species in glacial refugia often lead to hybridization while also playing a critical role in strengthening species barriers through reinforcement and character displacement. For example, in the case of the tyrant flycatchers in the Andes, population differentiation between lineages was reinforced during the last interglacial period, when isolated montane populations came in contact due to a shift in habitat ${ }^{10}$.

Effect of the Quaternary glacial cycles are also observed in the species-rich tropics, wherein during the glacial periods, the sea level drops as most of the sea water gets locked up as ice, allowing for land connectivity (Fig. 2) ${ }^{3}$. The formation of land bridges enables the movement of individuals between populations across isolated landmasses leading to the homogenization of the gene pool ${ }^{23}$. Depending on the species biology these land bridges act as semipermeable conduits of gene flow ${ }^{23}$. For example, many bulbuls which can move across large distances in search for fruiting trees were able to utilize these Pleistocene land bridges but the same was not observed for insectivorous understory babblers which are comparatively sedentary in nature (Figs. $1 \mathrm{~b}$ and 2) ${ }^{14}$. Similarly, in the satellite islands of Sulawesi, Peleng and Taliabu, forest-dependent bird species rarely utilized these land bridges to move between isolated island populations leading to genetic diversification and speciation, whereas edge tolerant species were able to move across the land bridges thereby retaining genetic connectivity and resisting genetic differentiation ${ }^{23}$.

In addition to historical habitat changes, more recent alterations owing to human influences have proven to be a major barrier for animal movement thus hindering genetic connectivity between populations leading to inbreeding and heightened risk of extirpation. With the current climate crisis and the lightning speed of urbanization, species are now facing unprecedented habitat loss and genetic isolation that they have not faced in their evolutionary history. For example, highways prevent movement and gene flow between populations of desert bighorn sheep in the California and have led to around 15\% decline in genetic diversity in only 40 years ${ }^{18}$. Similarly, simulation studies have suggested the importance of gene flow in maintaining current genetic diversity in tigers for the next 150 years ${ }^{2}$. In the absence of gene flow, within 25 years, even the large diverse populations of Tigers from Western Ghats will lose genetic diversity at an unprecedented rate due to genetic drift ${ }^{2}$. Even volant vertebrates are not immune to habitat destruction and lack of gene flow and loss of genetic diversity is observed. Genetic differentiation, due to habitat destruction was observed in insectivores birds in the island of Singapore ${ }^{15}$. Due to habitat destruction, forest-dependent understorey birds are unable to move between forest patches ${ }^{15}$. Similarly, in the Sholas of the Western Ghats, habitat loss has prevented the endemic White-bellied Shortwings from moving across recently fragmented habitats ${ }^{71}$. Even differences in song were observed between two patches, suggesting growing isolation and population differentiation ${ }^{71}$. Similar results were also observed in bats in disturbed landscapes in the neotropics ${ }^{50}$. However, we have only now started to understand the patterns of habitat fragmentation across 
Asia ${ }^{50}$. A study on genetic connectivity and diversity of bats in Peninsular Malaysia noted that the loss of pristine habitat was especially problematic for forest dependent weak fliers and large areas of intact forests are needed to be conserved to prevent any further loss in genetic diversity ${ }^{78}$.

One of the hallmarks of Anthropocene is the ongoing episode of climate change ${ }^{13}$. Many species are now facing new selection pressures such as increased duration of high temperatures, shorter winters, drought, etc. Range shift, change in reproduction timing, growth rate, etc. are observed in many species as a response to the current climate crises ${ }^{32}$. Further, decrease in population and/or range size is observed in many vertebrates ${ }^{32}$. Mass mortality is now commonly observed in bats in Australia and Southeast Asia due to heat strokes ${ }^{60}$. A comparison of 177 mammals indicated that $40 \%$ of the species have experienced population decrease and all species have lost nearly $30 \%$ of suitable habitat ${ }^{8}$. Loss of habitat along with range reduction can directly reduce gene flow between populations, further leading to isolation and loss of genetic diversity ${ }^{8}$. Gene flow is necessary especially if a species has to successfully respond to selection pressures that climate change exerts, firstly by introducing novel diversity for selection to act upon, and secondly by providing an avenue for the spread of possibly advantageous alleles ${ }^{32,66}$. However, the selection of advantageous alleles largely depends on the balance between selection and gene flow ${ }^{32,66}$. Climate change has also accelerated the pace of hybridizations ${ }^{12}$. Due to recent range shifts mediated by recent climate change, many allopatric species have come in contact with each other and hybridization is now common in many species which otherwise were not known to interbreed in the wild ${ }^{12}$. For example, increasing temperatures might lead to an increase in incidents of hybridization between Willow grouse and rock ptarmigan in Sweden ${ }^{68}$. In South and Southeast Asia, similar trends are visible as well and many montane species are moving to higher altitudes due to gradual rise in temperature, thereby allowing for the interaction between previously isolated species pairs. Thus, the cumulative interaction of species biology, ecology, climate change along with geographical features will play an important role in determining the movement of individuals and the levels of gene flow across geographically isolated populations/ species.

\section{Gene Flow as an Agent of Spread of Infectious Diseases}

The past two decades have witnessed a surge in the emergence of numerous infectious diseases in natural populations, which are further exacerbated with the threat of present climate change brought about by human activities ${ }^{16,34}$. Emerging infectious diseases can have devastating effect on species demography, cause population fragmentation, population subdivision, isolation, and even extirpation ${ }^{16,48}$. The effect of infectious diseases on gene flow is similar to habitat destruction and the spread of and co-evolution of host/ pathogens are tightly linked with gene flow potential ${ }^{48}$. Species with higher levels of gene flow tend to have higher genetic diversity and evolutionary potential to respond to changing selection pressures ${ }^{48}$. An increase in levels of gene flow can bring in the necessary genetic variability required for selection to act upon and allow for emergence of pathogen resistance within the populations ${ }^{48}$ and references therein). However, high levels of gene flow can also lead to the spread of the infectious diseases across susceptible and uninfected populations. Introduction of Pseudogymnoascus destructans, a fungus that causes white-nose syndrome in bats from Eurasia to North America, led to one of the worst infectious disease outbreak recoded in recent times and decimated millions of bats in just a few years ${ }^{33}$. While the Eurasian bats were resistant to the fungus, the North American bats were highly susceptible and high levels of gene flow, allowed the fungus to spread across North America and Canada ${ }^{33}$. Similarly, pathogenic strains of avian influenza can be carried across the globe by migratory birds ${ }^{42}$. Highly pathogenic avian influenza subtype H5N8 outbreak occurred in South Korea in 2013-2014, which later spread to Japan, Europe, and North America most likely by long-distant migratory water birds ${ }^{42}$. Thus high levels of gene flow can also be harmful to the species. South and Southeast Asia are a hot-bed for emerging infectious diseases, particularly zoonotic infections. However, work on the spread of infectious diseases in this region has only beginning to take shape and a major push in this area is necessary, especially given how the current pandemic has panned out.

\section{Gene Flow and Islands as Drivers of Biodiversity}

Island systems serve as the most interesting model to study gene flow. Although, islands tend to be species poor in comparison to continental landmasses, they are engines of diversification and
Anthropocene: Current geological age where humans have had a dramatic impact on the ecosystem and the climate, leading to the sixth mass extinction. 
contribute disproportionately to species biodiversity compared to the area they cover ${ }^{70,90}$. Species richness on islands is dependent on the size of the island, distance to mainland ${ }^{43}$. Species composition on islands is a balance between immigration, extinction and speciation ${ }^{40,43,90}$. Further, the Quaternary glacial cycles contribute disproportionately to the biodiversity of islands ${ }^{88}$. Islands, acting as isolated landmasses surrounded by large mass of water impedes gene flow between not only terrestrial life forms but also between freshwater aquatic organisms.

Terrestrial animals find it difficult to cross the oceanic barriers in comparison to volant vertebrates. Thus rate of immigration and distance to the nearest mainland becomes an important factor determining species composition ${ }^{43}, 90$. Further, land bridges formed during the Quaternary glacial maxima allow for terrestrial biota to occupy remote islands (Fig. 2) ${ }^{23,88}$. For example, the presence of large mammals like rhinoceros, orangutans, and elephants on the isolated island of Borneo, suggests that these land bridges may have played a role in the movement of these animals from continent to islands ${ }^{19}, 47,57$. However, it is easier for vagile animals to occupy remote islands ${ }^{20,29}$. Thus many remote islands are generally inhabited by volant vertebrates. The ability to fly, allows for genetic connectivity between isolated populations and reduces genetic differentiation ${ }^{20,29}$. In birds, rate of diversification and differentiation is dependent on dispersal ability measured as a function of wing morphology ${ }^{87}$.

Species with high dispersal ability can move across complex landscapes and reduce any differentiation that has been built-up overtime, leading to a lower rate of speciation as observed in Australasia ${ }^{87}$. Conversely, some of the most interesting examples of speciation are also from species with high dispersal rates. For example, the white-eyes complex of birds, one of the classic examples of 'great speciators' comprises of approximately 100 species in the old world, most of them being restricted to islands ${ }^{26,52}$. Great speciators paradoxically can disperse across great distances, often colonizing entire archipelagos but diversifying at the same time ${ }^{17,26,52}$. Recent work on the phylogenomic relationships between various taxa revealed Borneo to be the major centre for diversity and an evolutionary hotspot for the white-eyes ${ }^{26}$. Another interesting example comes from the largest group of bats, the flying foxes. At least 65 species of the flying foxes belonging to the genuse Pteropus are known to science. They are present on every island of the Indo-Australian archipelago and often are the only native land mammals on these islands ${ }^{85}$. They are one of the largest known flying mammals often known to fly $\sim 100 \mathrm{~km}$ in a single night ${ }^{85}$. Although, they are strong flyers, their ability to colonize new habitats like the white-eyes has led to a rapid radiation with this group leading to a high species diversity ${ }^{85}$. Thus, the ability to fly and occupy distant islands can also to lead to isolation and speciation.

Similar to natural islands, availability of suitable habitat also mimics isolating effects observed in islands and habitat specialists often find it difficult to move across habitats when they are separated by unfavourable patch or biogeographic barriers. The sky island ecosystem is an excellent example of such island effect observed in continental landmasses ${ }^{72}$. Earth-historic factors play an important role in periodic connectivity and isolation between such isolated landmasses ${ }^{30,31}$. Within continental landmasses, climate change can expand or contract favourable habitats thereby controlling the extent of genetic connectivity between populations of habitat specialists ${ }^{10}$. Over the course of time, these events increase population differentiation, ultimately leading to speciation or conversely wipe out any differentiation that may have built up over time, depending on the species requirements. In the Western Ghats, comparison of bird community across the sky islands in the Ghats, suggests that only a few species were affected by the Palghat Gap, a natural gap in the Western Ghats mountain ranges. More than half the species of birds showed no differentiation across the Palghat Gap, suggesting possible movement of montane birds across the barrier, especially during the cooling periods of the glacial cycle ${ }^{72}$.

\section{More Markers Bring Better Resolution: Genomic Revolution in Gene Flow of Volant Vertebrates}

The ease of availability of the ever-growing repository of genomic data for non-model species obtained from NGS platforms has exponentially increased our knowledge about the effects of dispersal and gene flow ${ }^{77}$. With the availability of thousands of genome-wide markers, it is now possible to acquire a complete picture of the genomic changes that occur due to gene flow. The power in detecting and quantifying levels and timing of gene flow has dramatically improved $^{77}$. For example, results based on a handful of genetic markers suggested gene flow between two species of fruit bats in Southern India, but an investigation with thousands of 
genome-wide markers this signal disappeared highlighting the lack of power of fewer makers to correctly identify gene flow. Further, this same panel of genome-wide markers could also identify a cryptic species of fruit bat from Eastern India and discovered a hybrid zone between two species-level lineages with evidence of gene flow and introgression ${ }^{11}$. NGS data has also helped in identifying various barriers to gene flow like physical features of the Earth (e.g rivers and oceans) as well as species attributes (e.g habitat preferences) ${ }^{14,23,41,56}$. For instance, unexpected fine-scale populations structure was revealed in forest-dependent birds within a small forested region of the island nation of Singapore when thousands of genomic markers were used ${ }^{15}$. Although, we have made great progress in utilizing NGS data for volant vertebrates, but our knowledge is still in its infancy especially for bats, where only a handful of studies exist. Future studies need to incorporate new technological advancements in addressing pertinent questions regarding speciation and gene flow.

\section{Take-Home Message and Future Directions}

Gene flow is a potent evolutionary force that improves genetic diversity, affects speciation, and plays a significant role in shaping biotic diversity. Gene flow is governed by the interplay of species history, biology, ecology as well as the environment. Volant vertebrates reveal similar trends as terrestrial animals, however owing to their ability to fly, the extent of gene flow may be higher in them thereby helping them to act as great dispersers and colonizers across remote and diverse landscapes. In this review, we have highlighted some of the important research on gene flow that has been carried out in South and Southeast Asia. Among volant vertebrates, most of our understanding of various evolutionary process and theories are based on extensive work on birds. However, bats being the only group of true volant mammals provide a unique system to understand selection, dispersal and adaptation. They are the second most specious group of mammals and are excellent bioindicators, but are comparatively less represented in research investigations targeting gene flow in natural populations. While few studies have utilized NGS data to understand gene flow and speciation in bats and birds, extensive efforts in the near future are necessary to develop general models of diversification and differentiation of volant vertebrates in the Indian subcontinent in general and bats in particular. In addition, most studies from the subcontinent report species-specific patterns of gene flow, necessitating future research programs targeting community-wide patterns of gene flow in this region. Going forward, such community-wide investigations would play a pivotal role in shaping our understanding of large-scale patterns of population structure and gene flow in natural populations of volant vertebrates.

\section{Publisher's Note}

Springer Nature remains neutral with regard to jurisdictional claims in published maps and institutional affiliations.

\section{Acknowledgements}

KMG acknowledges support from the Ramanujan Fellowship of SERB and is currently supported by the DBT-Ramalingaswami Fellowship (No. BT/HRD/35/02/2006). BC acknowledges startup funding from Trivedi School of Biosciences, Ashoka University. The authors also thank the reviewers and the editor for their comments and suggestions.

\section{Declarations}

\section{Conflict of Interest}

On behalf of all authors, the corresponding author states that there is no conflict of interest.

Received: 16 January 2021 Accepted: 5 May 2021

Published online: 16 June 2021

\section{References}

1. Anderson SH, Kelly D, Robertson AW, Ladley JJ (2016) Pollination by Birds: a functional analysis. In: Sekercioglu CJ (ed) Why birds matter: Avian ecological function and ecosystem services. University of Chicago Press, Chicago, pp 73-106

2. Bay RA, Ramakrishnan U, Hadly EA (2014) A call for tiger management using "reserves" of genetic diversity. J Hered 105(3):295-302

3. Bintanja R, Van De Wal RS, Oerlemans J (2005) Modelled atmospheric temperatures and global sea levels over the past million years. Nature 437(7055):125128

4. Bock CE, Jones ZF (2004) Avian habitat evaluation: should counting birds count? Front Ecol Environ 2(8):403-410

5. Bohonak AJ (1999) Dispersal, gene flow, and population structure. Q Rev Biol 74(1):21-45 
6. Burger J, Gochfeld M (2004) Marine birds as sentinels of environmental pollution. EcoHealth 1(3):263-274

7. Burney CW, Brumfield RT (2009) Ecology predicts levels of genetic differentiation in Neotropical birds. Am Nat 174(3):358-368

8. Ceballos G, Ehrlich PR, Dirzo R (2017) Biological annihilation via the ongoing sixth mass extinction signaled by vertebrate population losses and declines. Proc Natl Acad Sci USA 114(30):E6089-E6096

9. Chakravarty R, Chattopadhyay B, Ramakrishnan U, Sivasundar A (2018) Comparative population structure in species of bats differing in ecology and morphology in the Andaman Islands India. Acta Chiropterol 20(1):85-98

10. Chattopadhyay B, Garg KM, Gwee CY, Edwards SV, Rheindt FE (2017) Gene flow during glacial habitat shifts facilitates character displacement in a Neotropical flycatcher radiation. BMC Evol Biol 17(1):210

11. Chattopadhyay B, Garg KM, Kumar AV, Doss DPS, Rheindt FE, Kandula S et al (2016) Genome-wide data reveal cryptic diversity and genetic introgression in an Oriental cynopterine fruit bat radiation. BMC Evol Biol 16(1):1

12. Chunco AJ (2014) Hybridization in a warmer world. Ecol Evol 4(10):2019-2031

13. Corlett RT (2015) The Anthropocene concept in ecology and conservation. Trends Ecol Evol 30(1):36-41

14. Cros E, Chattopadhyay B, Garg KM, Ng NS, Tomassi S, Benedick S et al (2020) Quaternary land bridges have not been universal conduits of gene flow. Mol Ecol 29(14):2692-2706

15. Cros E, Ng EY, Oh RR, Tang Q, Benedick S, Edwards DP et al (2020) Fine-scale barriers to connectivity across a fragmented South-East Asian landscape in six songbird species. Evol Appl 13(5):1026-1036

16. Daszak P, Cunningham AA, Hyatt AD (2000) Emerging infectious diseases of wildlife-threats to biodiversity and human health. Science 287(5452):443-449

17. Diamond JM, Gilpin ME, Mayr E (1976) Species-distance relation for birds of the Solomon Archipelago, and the paradox of the great speciators. Proc Natl Acad Sci USA 73(6):2160-2164

18. Epps CW, Palsbøll PJ, Wehausen JD, Roderick GK, Ramey RR, McCullough DR (2005) Highways block gene flow and cause a rapid decline in genetic diversity of desert bighorn sheep. Ecol Lett 8(10):1029-1038

19. Fernando P, Vidya TC, Payne J, Stuewe M, Davison G, Alfred RJ et al (2003) DNA analysis indicates that Asian elephants are native to Borneo and are therefore a high priority for conservation. PLoS Biol 1(1):e6

20. Fleming TH, Racey PA (2010) Island bats: evolution, ecology, and conservation. University of Chicago Press, Chicago

21. Frankham R (2015) Genetic rescue of small inbred populations: Meta-analysis reveals large and consistent benefits of gene flow. Mol Ecol 24(11):2610-2618
22. Garant D, Forde SE, Hendry AP (2007) The multifarious effects of dispersal and gene flow on contemporary adaptation. Funct Ecol 21:434-443

23. Garg KM, Chattopadhyay B, Wilton PR, Prawiradilaga DM, Rheindt FE (2018) Pleistocene land bridges act as semipermeable agents of avian gene flow in Wallacea. Mol Phylogenet Evol 125:196-203

24. Gill FB (1980) Historical aspects of hybridization between Blue-winged and Golden-winged warblers. Auk 97(1):1-18

25. Greenwood PJ (1980) Mating systems, philopatry and dispersal in birds and mammals. Anim Behav 28(4):1140-1162

26. Gwee CY, Garg KM, Chattopadhyay B, Sadanandan KR, Prawiradilaga DM, Irestedt M et al (2020) Phylogenomics of white-eyes, a 'great speciator', reveals Indonesian archipelago as the center of lineage diversity. Elife 9:e62765

27. Hamer S, Lehrer E, Magle S (2012) Wild birds as sentinels for multiple zoonotic pathogens along an urban to rural gradient in greater Chicago Illinois. Zoonoses Public Health 59(5):355-364

28. Harrison RG, Larson EL (2014) Hybridization, introgression, and the nature of species boundaries. J Hered 105(S1):795-809

29. Heaney LR, Walsh JS Jr, Townsend Peterson A (2005) The roles of geological history and colonization abilities in genetic differentiation between mammalian populations in the Philippine archipelago. J Biogeogr 32(2):229-247

30. Hewitt GM (2000) The genetic legacy of the Quaternary ice ages. Nature 405(6789):907-913

31. Hewitt GM (2004) Genetic consequences of climatic oscillations in the Quaternary. Philos Trans R Soc Lond Ser B Biol Sci 359(1442):183-195

32. Hoffmann AA, Sgrò CM (2011) Climate change and evolutionary adaptation. Nature 470(7335):479-485

33. Hoyt JR, Kilpatrick AM, Langwig KE (2021) Ecology and impacts of white-nose syndrome on bats. Nat Rev Microbiol 19:1-15

34. Jones KE, Patel NG, Levy MA, Storeygard A, Balk D, Gittleman JL, Daszak P (2008) Global trends in emerging infectious diseases. Nature 451(7181):990-993

35. Jones G, Jacobs DS, Kunz TH, Willig MR, Racey PA (2009) Carpe noctem: the importance of bats as bioindicators. Endanger Species Res 8(1-2):93-115

36. Kerth G, Mayer F, Petit E (2002) Extreme sex-biased dispersal in the communally breeding, nonmigratory Bechstein's bat (Myotis bechsteinii). Mol Ecol 11(8):1491-1498

37. Lamichhaney S, Han F, Webster MT, Andersson L, Grant BR, Grant PR (2018) Rapid hybrid speciation in Darwin's finches. Science 359(6372):224-228

38. Larsen PA, Marchán-Rivadeneira MR, Baker RJ (2010) Natural hybridization generates mammalian lineage with species characteristics. Proc Natl Acad Sci USA 107(25):11447-11452 
39. Letko M, Seifert SN, Olival KJ, Plowright RK, Munster VJ (2020) Bat-borne virus diversity, spillover and emergence. Nat Rev Microbiol 18:1-11

40. Lomolino MV (2000) A call for a new paradigm of island biogeography. Glob Ecol Biogeogr 9(1):1-6

41. Loureiro LO, Engstrom MD, Lim BK (2020) Comparative phylogeography of mainland and insular species of Neotropical molossid bats (Molossus). Ecol Evol 10(1):389-409

42. Lycett S, Bodewes R, Pohlmann A, Banks J, Banyai K, Boni M, Bouwstra R, Breed A, Brown I, Chen $\mathrm{H}$, GlobalConsortium for H5N8 and Related Influenza Viruses (2016) Role for migratory wild birds in the global spread ofavian influenza H5N8. Science 354:213-217

43. MacArthur RH, Wilson EO (1967) The theory of island biogeography, vol 1. Princeton University Press, UK

44. Mallet J (2005) Hybridization as an invasion of the genome. Trends Ecol Evol 20(5):229-237

45. Marko PB, Hart MW (2011) The complex analytical landscape of gene flow inference. Trends Ecol Evol 26(9):448-456

46. Marshall JL, Arnold ML, Howard DJ (2002) Reinforcement: the road not taken. Trends Ecol Evol 17(12):558-563

47. Mays HL Jr, Hung C-M, Shaner P-J, Denvir J, Justice M, Yang S-F et al (2018) Genomic analysis of demographic history and ecological niche modeling in the endangered Sumatran rhinoceros Dicerorhinus sumatrensis. Curr Biol 28(1):70-76.e74

48. McKnight DT, Schwarzkopf L, Alford RA, Bower DS, Zenger KR (2017) Effects of emerging infectious diseases on host population genetics: a review. Conserv Genet 18(6):1235-1245

49. Medina I, Cooke GM, Ord TJ (2018) Walk, swim or fly? Locomotor mode predicts genetic differentiation in vertebrates. Ecol Lett 21(5):638-645

50. Meyer CF, Struebig MJ, Willig MR (2016) Responses of tropical bats to habitat fragmentation, logging, and deforestation. In: Voigt CC, Kingston T (eds) Bats in the anthropocene: conservation of bats in a changing world. Springer, pp 63-103

51. Moussy C, Hosken D, Mathews F, Smith G, Aegerter J, Bearhop S (2013) Migration and dispersal patterns of bats and their influence on genetic structure. Mammal Rev 43(3):183-195

52. Moyle RG, Filardi CE, Smith CE, Diamond J (2009) Explosive Pleistocene diversification and hemispheric expansion of a "great speciator." Proc Natl Acad Sci USA 106(6):1863-1868

53. Myers N, Mittermeier RA, Mittermeier CG, Da Fonseca GA, Kent J (2000) Biodiversity hotspots for conservation priorities. Nature 403(6772):853-858

54. Myhrvold NP, Baldridge E, Chan B, Sivam D, Freeman DL, Ernest SM (2015) An amniote life-history database to perform comparative analyses with birds, mammals, and reptiles: ecological archives E096-269. Ecology 96(11):3109-3109

55. Nabi G, Wang Y, Lü L, Jiang C, Ahmad S, Wu Y, Li D (2021) Bats and birds as viral reservoirs: a physiological and ecological perspective. Sci Total Environ 754:142372

56. Naka LN, Brumfield RT (2018) The dual role of Amazonian rivers in the generation and maintenance of avian diversity. Sci Adv 4(8):eaar8575

57. Nater A, Mattle-Greminger MP, Nurcahyo A, Nowak MG, De Manuel M, Desai T et al (2017) Morphometric, behavioral, and genomic evidence for a new orangutan species. Curr Biol 27(22):3487-3498.e3410

58. Norris LC, Main BJ, Lee Y, Collier TC, Fofana A, Cornel AJ et al (2015) Adaptive introgression in an African malaria mosquito coincident with the increased usage of insecticide-treated bed nets. Proc Natl Acad Sci USA 112(3):815-820

59. Nosil P (2012) Ecological speciation. Oxford University Press, Oxford

60. O'Shea TJ, Cryan PM, Hayman DT, Plowright RK, Streicker DG (2016) Multiple mortality events in bats: a global review. Mammal Rev 46(3):175-190

61. Ottenburghs J, Kraus RH, van Hooft P, van Wieren SE, Ydenberg RC, Prins HH (2017) Avian introgression in the genomic era. Avian Res 8(1):30

62. Ouborg NJ, Piquot Y, Van Groenendael JM (1999) Population genetics, molecular markers and the study of dispersal in plants. J Ecol 87(4):551-568

63. Pabijan M, Wollenberg K, Vences M (2012) Small body size increases the regional differentiation of populations of tropical mantellid frogs (Anura: Mantellidae). J Evol Biol 25(11):2310-2324

64. Pardo-Diaz C, Salazar C, Baxter SW, Merot C, Figueiredo-Ready W, Joron M et al (2012) Adaptive introgression across species boundaries in Heliconius butterflies. PLoS Genet 8(6):e1002752

65. Parreira BR, Chikhi L (2015) On some genetic consequences of social structure, mating systems, dispersal, and sampling. Proc Natl Acad Sci USA 112(26):E3318-E3326

66. Pauls SU, Nowak C, Bálint M, Pfenninger M (2013) The impact of global climate change on genetic diversity within populations and species. Mol Ecol 22(4):925-946

67. Pusey AE (1987) Sex-biased dispersal and inbreeding avoidance in birds and mammals. Trends Ecol Evol 2(10):295-299

68. Quintela M, Thulin CG, Höglund J (2010) Detecting hybridization between willow grouse (Lagopus lagopus) and rock ptarmigan (L. muta) in Central Sweden through Bayesian admixture analyses and mtDNA screening. Conserv Genet 11(2):557-569

69. Rheindt FE, Edwards SV (2011) Genetic introgression: an integral but neglected component of speciation in birds. Auk 128(4):620-632

70. Rheindt FE, Prawiradilaga DM, Ashari H, Gwee CY, Lee GW, Wu MY et al (2020) A lost world in Wallacea: 
description of a montane archipelagic avifauna. Science 367(6474):167-170

71. Robin V, Gupta P, Thatte P, Ramakrishnan U (2015) Islands within islands: two montane palaeo-endemic birds impacted by recent anthropogenic fragmentation. Mol Ecol 24(14):3572-3584

72. Robin V, Vishnudas C, Gupta P, Ramakrishnan U (2015) Deep and wide valleys drive nested phylogeographic patterns across a montane bird community. Proc R Soc B Biol Sci 282(1810):20150861

73. Sheard C, Neate-Clegg MH, Alioravainen N, Jones SE, Vincent C, MacGregor HE, Bregman TP, Claramunt S, Tobias JA (2020) Ecological drivers of global gradients in avian dispersal inferred from wing morphology. Nat Commun 11(1):1-9

74. Slatkin M (1985) Gene flow in natural populations. Annu Rev Ecol Syst 16(1):393-430

75. Slatkin M (1987) Gene flow and the geographic structure of natural populations. Science 236(4803):787-792

76. Song Y, Endepols S, Klemann N, Richter D, Matuschka F-R, Shih C-H et al (2011) Adaptive introgression of anticoagulant rodent poison resistance by hybridization between old world mice. Curr Biol 21(15):1296-1301

77. Sousa V, Hey J (2013) Understanding the origin of species with genome-scale data: modelling gene flow. Nat Rev Genet 14(6):404-414

78. Struebig MJ, Kingston T, Petit EJ, Le Comber SC, Zubaid A, Mohd-Adnan A et al (2011) Parallel declines in species and genetic diversity in tropical forest fragments. Ecol Lett 14(6):582-590

79. Sutherland GD, Harestad AS, Price K, Lertzman KP (2000) Scaling of natal dispersal distances in terrestrial birds and mammals. Conserv Ecol 4(1), http://www. consecol.org/vol4/iss1/art16

80. Szulkin M, Sheldon BC (2008) Dispersal as a means of inbreeding avoidance in a wild bird population. Proc $\mathrm{R}$ Soc B: Biol Sci 275(1635):703-711

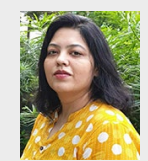

Dr. Kritika Garg is an evolutionary biologist specializing in population genetics and behavioral ecology. She is interested in understanding the genomic underpinnings of mate choice in natural populations and the role of mate choice in aiding speciation.

She is currently a Ramalingaswami Fellow at Department of Biology, Ashoka University.
81. Tamma K, Ramakrishnan U (2015) Higher speciation and lower extinction rates influence mammal diversity gradients in Asia. BMC Evol Biol 15(1):11

82. Thatte P, Chandramouli A, Tyagi A, Patel K, Baro P, Chhattani $\mathrm{H}$ et al (2020) Human footprint differentially impacts genetic connectivity of four wide-ranging mammals in a fragmented landscape. Divers Distrib 26(3):299-314

83. Todesco M, Pascual MA, Owens GL, Ostevik KL, Moyers BT, Hübner S et al (2016) Hybridization and extinction. Evol Appl 9(7):892-908

84. Toews DP, Taylor SA, Vallender R, Brelsford A, Butcher BG, Messer PW et al (2016) Plumage genes and little else distinguish the genomes of hybridizing warblers. Curr Biol 26(17):2313-2318

85. Tsang SM, Wiantoro S, Veluz MJ, Sugita N, Nguyen YL, Simmons NB et al (2020) Dispersal out of Wallacea spurs diversification of Pteropus flying foxes, the world's largest bats (Mammalia: Chiroptera). J Biogeogr 47(2):527-537

86. Voris HK (2000) Maps of Pleistocene sea levels in Southeast Asia: shorelines, river systems and time durations. J Biogeogr 27(5):1153-1167

87. Weeks BC, Claramunt S (2014) Dispersal has inhibited avian diversification in Australasian archipelagoes. Proc R Soc B: Biol Sci 281(1791):20141257

88. Weigelt P, Steinbauer MJ, Cabral JS, Kreft H (2016) Late Quaternary climate change shapes island biodiversity. Nature 532(7597):99-102

89. Whitlock MC, Mccauley DE (1999) Indirect measures of gene flow and migration: FST $\neq 1 /(4 \mathrm{Nm}+1)$. Heredity 82(2):117-125

90. Whittaker RJ, Fernández-Palacios JM (2007) Island biogeography: ecology, evolution, and conservation. Oxford University Press, Oxford

91. Wilkinson G, Fleming T (1996) Migration and evolution of lesser long-nosed bats Leptonycteris curasoae, inferred from mitochondrial DNA. Mol Ecol 5(3):329-339

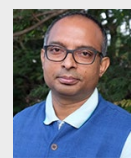

Dr. Balaji Chattopdhyay is an Assistant Professor at the Trivedi School of Biosciences. His research aims to understand the evolution of natural populations, including behavioural ecology, gene flow and speciation, historical demography, conservation genomics and host-pathogen coevolution. Dr. Chattopadhyay is currently studying the effects of climate change on wildlife and the potential link between wildlife endangerment and zoonotic infections. 